\title{
Administration, Management
}

National Cancer Institute

\section{Source}

National Cancer Institute. Administration, Management. NCI Thesaurus. Code C48905.

Performing or possessing executive duties; acting as a supervisor or manager. 